\title{
Upaya Meningkatkan Hasil Belajar Siswa pada Mata Pelajaran Sejarah Kebudayaan Islam melalui Strategi Inferencing
}

\author{
Tetin \\ Institut Agama Islam Darussalam (IAID), Ciamis-Jawa Barat \\ Email: tetin.cms564@gmail.com \\ N. Hani Herlina \\ Institut Agama Islam Darussalam (IAID), Ciamis-Jawa Barat \\ Tanto Aljauharie Tantowie \\ Institut Agama Islam Darussalam (IAID), Ciamis-Jawa Barat
}

\begin{abstract}
This research is motivated by the level of completeness of the learning outcomes of class III students of MI Rijalul Hikam Jatinagara, Jatinagara District, Ciamis Regency, which is still low in the SKI subject. The average student learning outcomes in the SKI subject obtained by students are still below the minimum completeness criteria of 75 . However, the reality shows that $30 \%$ of 17 students have not reached the KKM while $70 \%$ of 17 students have reached the KKM. This is because the learning process is more teacher-centered and monotonous. Learning activities are mostly used to take notes so that students become bored. This situation makes students less understanding of the material being taught and easy to forget so that it affects the low student learning outcomes. The research method used was Classroom Action Research (CAR) with Kurt Lewin's model. The sequence of activities in Kurt Lewin's model is planning, acting, observing and reflecting. The data collection techniques used in this research were test, observation, interview and descriptive analysis techniques. Data analysis data selection, data correction and data weighting. After conducting the research, the following data can be obtained: 1) the ability of the teacher in preparing RPP SKI in the first cycle reaches an average of 82.61 (good); in cycle II reached 86.5 (Good); and in the third cycle reached an average of 93.14 (very good), 2) the ability of teachers to carry out the learning process of the IEC learning process in the first cycle reached an average of 79.02 (good); in cycle II reached an average value of 86.5 (good); and in cycle III reached an average value of 93.33 (very good). 3) student learning outcomes in the first cycle reached 83.05 (good) with $70.5 \%$ completeness in the calculation of 12 students completed, 5 students have not completed. In cycle II it reaches an average of 88.23 (good) with completeness $88.23 \%$ on the calculation of 15 students complete, 2 students have not completed and in cycle III reaches an average value of 92.88 (good) with $100 \%$ completeness in the calculation all students (22 students) completed. This
\end{abstract}


proves that the Inferencing strategy (concluding) can improve student learning outcomes.

Keywords: Inferencing, learning outcomes, Islamic Cultural History

\section{PENDAHULUAN}

Tujuan pendidikan Nasional yang tercantum dalam UndangUndang Sistem Pendidikan Nasional No. 20/2003 Bab 1 Pasal (o3) yang berbunyi "pendidikan nasional bertujuan untuk berkembangnya peserta didik agar menjadi manusia yang beriman dan bertakwa kepada Tuhan Yang Maha Esa, berakhlak mulia, sehat, berilmu, cakap, kreatif, mandiri dan menjadi warga negara yang demokratis serta bertanggung jawab”.

Berdasarkan tujuan pendidikan di atas, maka dalam kaitannya untuk mencerdaskan anak bangsa Indonesia pada pelajaran SKI, pemerintah pun menetapkan proses pembelajaran sesuai dengan Peraturan Pemerintah RI No. 19/2005, pasal (19) yaitu: "Proses pembelajaran pada satuan pendidikan diselenggarakan secara interaktif, berfartisifatif, serta memberikan ruang yang cukup bagi prakarsa, kreativitas dan kemandirian sesuai dengan bakat, minat, dan perkembangan fisik serta psikologi peserta didik.

Proses belajar merupakan suatu rangkaian proses kegiatan respons yang terjadi dalam proses belajar mengajar yang menimbulkan perubahan tingkah laku sebagai akibat dari pengalaman dan pengetahuan yang diperoleh (Ramayulis, 2008: 26). Berdasarkan pengertian tersebut diperlukan kreativitas dalam mengajar agar peserta didik dapat menata serta menghubungkan pengalaman dan pengetahuan yang dimilikinya sehingga membentuk satu kesatuan.

Pendidikan Sejarah Kebudayaan Islam (SKI) adalah berupa materi mata pelajaran yang diberikan di sekolah-sekolah yang bercirikan agama Islam yakni pada MI, MTS dan MA. Madrasah Ibtidaiyah merupakan lembaga pendidikan dasar yang berciri khas Islam yang berada dibawah naungan Departemen Agama. Khusus pada mata pelajaran SKI di Madrasah Ibtidaiyah (MI) merupakan salah satu mata pelajaran PAI yang menelaah tentang asal usul, perkembangan, peranan, kebudayaan/peradaban Islam dan para tokoh yang berprestasi dalam sejarah Islam dimasa lampau mulai dari sejarah masyarakat Arab praIslam, sejarah kelahiran dan kerasulan Nabi Muhammad saw, sampai kulafaurasyidin. Secara substansial mata pelajaran SKI memiliki kontribusi dalam memberikan motivasi kepada siswa untuk mengenal, memahami, menghayati, yang mengandung nilai-nilai kearifan yang dapat digunakan untuk melatih kecerdasan, membentuk sikap, watak, dan kepribadian sisa (Nadia, 2008:46).

Pemilihan strategi dapat diterapkan dalam berbagai pembelajaran, termasuk pembelajaran SKI merupakan salah satu 


\section{BESTARI}

Vol. 18, No. 1, 2021

p-ISSN 1907-1337; e-ISSN 2807-6532

rumpun dari mata pelajaran Pendidikan Agama Islam yang wajib dipelajari oleh siswa. Berdasarkan peraturan kementrian Agama dijelaskan bahwa:

Sejarah kebudayaan Islam (SKI) adalah mata pelajaran yang berisi mengenai catatan perkembangan perjalanan hidup manusia muslim dari masa ke masa dalam hal beribadah, bermuamalah serta berakhlak dalam mengembangkan sistem kehidupan atau menyebarkan agama Islam yang dilandasi oleh akidah (Peraturan Menteri Agama RI No.000912 Thn 2013: 35)

Dari pengertian tersebut dapat peneliti ketahui bahwa sejarah merupakan catatan peristiwa yang terjadi di masa lampau. Dengan belajar SKI berarti mengenal kembali segala peristiwa yang terjadi dan dialami umat Islam baik berupa perkembangan kemajuan maupun kemunduran. Namun pembelajaran SKI yang berlangsung selama ini masih sebatas transfer of knowledge yang kurang menekankan pada pemahaman dan pemaknaan, penyampaian materi masih sebatas pada pengetahuan kapan peristiwa itu terjadi, dimana peristiwa itu terjadi. Pembelajaran SKI kurang menitikberatkan pada sebab-akibat atau latar belakang dari suatu peristiwa yang terjadi yang dapat dijadikan ibrah, hikmah, dan dapat ditauladani di masa sekarang maupun masa yang akan datang ( Mansur 2004: 1).

Kenyataan di lapangan, praktik-praktik pembelajaran cenderung masih megabaikan gagasan, konsep, dan kemampuan berpikir siswa. Aktivitas guru lebih menonjol daripada siswa. Guru cenderung menggunakan metode ceramah dirasa cocok diterapkan pada materi SKI, mengingat SKI merupakan mata pelajaran yang berisi kisah-kisah, mereka merasa sulit memahami dikarenakan banyaknya materi yang harus diingat sehingga menimbulkan rasa bosan dan jenuh.

Prestasi belajar terkadang menjadi acuan penting dari akhir pembelajaran apakah hasil pembelajaran berhasil atau tidaknya. Akan tetapi hasil ini sangat sulit jika pengaruh-pengaruhnya kurang diperhatikan, karena setiap tujuan ada faktor pendukungnya. Mulai dari kesiapan guru dalam menyusun, mempersiapkan, melaksanakan pembelajaran serta evaluasi sebagai tindak akhir. Istilah prestasi belajar Menurut Hamalik, hasil belajar menunjuk pada prestasi belajar sedangkan hasil belajar merupakan indikator adanya derajat perubahan tingkah laku siswa (Hamalik, 2001).

Adapun proses pembelajaran SKI di MI Rijalul Hikam Jatinagara Kabupaten Ciamis, belum tercapai sesuai dengan tujuan pembelajaran, karena siswa kurang antusias dan mudah bosan dalam proses pelaksanaan pembelajaran, dan kurangnya guru dalam penyusunan Rencana Pelaksanaan Pembelajaran, serta kurangnya dalam pemahaman siswa terkait hasil belajar mata pelajaran SKI yang masih jauh dari KKM sebesar 75. Hal ini terlihat bahwa 30\% dari 17 siswa belum mencapai KKM, sementara 70\% dari 17 siswa sudah mencapai KKM (hasil 
wawancara dengan Bapak Aziz Hamdan Pauzi, S.Pd. guru kelas III MI Rijalul Hikam Jatinagara, 2 April 2019).

Dari hasil wawancara di MI Rijalul Hikam Jatinagara Kabupaten Ciamis, kegiatan pembelajaran membutuhkan inovasi pembelajaran agar para siswa menjadi bersemangat, mempunyai motivasi untuk belajar, dan antusias menyambut pelajaran di sekolah (hasil wawancara dengan Bapak Aziz Hamdan Pauzi, S.Pd. guru kelas III MI Rijalul Hikam Jatinagara, 13 April 2019).

Dengan permasalahan di atas penulis selaku peneliti menarik kesimpulan bahwa permasalahan tersebut penting untuk diteliti dan dipecahkan dengan melakukan tindakan yang akan meningkatkan pemahaman siswa serta terhadap materi-materi yang disampaikan dan penggunaan strategi pembelajaran yang dapat melibatkan aktivitas pesertadidik.

Tindakan yang diambil peneliti yaitu dengan merancang suatu bentuk pembelajaran yang aktif, kreatif, efektif, dan menyenangkan, menerapkan srategi inferencing sebagaimana yang telah dijelaskan bahwa srategi inferencing adalah menarik kesimpulan, penggunaan informasi makna butir-butir baru dan melengkapi bagian yang hilang.

Berdasarkan penelitian yang relevan yang pernah dilakukan oleh Siwi Mahanani Tahun 2013 dengan judul keefektifan penggunaan strategi inferencing dalam pembelajaran membaca pemahaman, menunjukkan bahwa penerapan strategi inferencing efektif digunakan dalam pembelajaran pemahaman siswa (Siwi, 2013).

\section{KAJIAN TEORI}

\section{Hasil Belajar Siswa}

Hasil belajar adalah kemampuan yang diperoleh anak setelah melalaui kegiatan belajar (Abrurahman, 1999). Belajar itu sendiri merupakan suatu proses dari seseorang yang berusaha untuk memperoleh suatu bentuk perubahan perilaku yang relatif menetap. Dalam kegiatan pembelajaran atau kegiatan instruksional, biasanya guru menetapkan tujuan belajar. Siswa yang berhasil dalam belajar adalah yang berhasil mencapai tujuan-tujuan pembelajaran atau tujuan instruksional.

Menurut Benjamin S. Bloom tiga ranah hasil belajar, yaitu kognitif, afektif, dan psikomotorik. Menurut A. J. Romizowski hasil belajar merupakan keluaran dari suatu sistem pemprosesan masukan. Masukan dari sistem tersebut berupa bermacam-macam informasi sedangakan keluarannya adalah perbuatan atau kinerja (Jihad, 2013: 1415).

Dapat kita simpulkan bahwa hasil belajar pencapaian bentuk perubahan perilaku yang cenderung menetap dari ranah kognitif, afektif, dan psikomotoris dari proses belajar yang di lakukan dalam waktu tertentu. 


\section{BESTARI}

Vol. 18, No. 1, 2021

p-ISSN 1907-1337; e-ISSN 2807-6532

a. Tipe-tipe Hasil Belajar Siswa

1) Tipe pengetahuan

Pengetahuan, jenjang yang paling rendah dalam kemampuan kognitif meliputi peningkatan tentang hal-hal yang bersifat khusus atau universal, mengetahui metode dan proses, pengingatan terhadap suatu pola, struktur atau seting.

Pemahaman, jenjang setingkat diatas pengetahuan ini meliputi penerimaan dalam komunikasi secara akurat, menempatkan hasil komunikasi dalam bentuk penyajian yang berbeda, mereorganisasikannya secara singkat tanpa merubah pengertian. Aplikasi atau penggunaan prinsip atau metode pada situasi yang baru.

Analisis, menyangkut terutama kemampuan anak dalam memisahmisah terhadap suatu materi menjadi bagian-bagian yang membentuknya, medeteksi hubungan di antara bagian-bagian itu dan cara materi itu diorganisir. Sintesis, merupakan lawan analisis. Tekanan pada kesanggupan menguraikan suatu integritas menjadi bagian yang bermakna, pada sintesis adalah kesanggupan menyatukan unsur atau bagian menjadi integritas.

Evalusai, merupakan kesanggupan memberikan keputusan tentang nilai sesuatu berdasarkan judgment yang dimilikinya, dan kriteria yang dipakainya.tipe hasil belajar ini dikategorikan paling tinggi, dalam tipe ini ditekankan pada pertimbangan sesuatu nilai, mengenai baik tidaknya, tepat tidaknya, dengan menggunakan kriteria tertentu (Sudjana, 2013: 52).

2) Tipe Hasil Belajar Afektif

Menerima, meliputi sifat sensitif terhadap adanya eksistensi suatu penomena tertentu atau suatu stimulus dan kesadaran yang merupakan perilaku kognitif. Merespon, peserta didik dilibatkan secara puas dalam suatu subjek tertentu, atau suatu kegiatan sehingga ia akan mencari-cari dan menambah kepuasan dari bekerja. Penghargaan, peserta didik adalah konsisten dan stabil, tidak hanya dalam persetujuan terhadap suatu nilai tetapi juga pemilihan terhadapnya.(Jihad, 2013: 16-18).

Penilaian, yakni berkenaan dengan nilai dan kepercayaan terhadap gejala atau stimulus tadi. Dalam evaluasi ini termasuk di dalamnya kesediaan menerima nilai, latar belakang atau pengalaman untuk menerima nilai, dan kesepakatan terhadap nilai tersebut. Organisasi, yakni pengembangan nilai ke dalam satu sistem organisasi, termasuk menentukan hubungan satu nilai dengan nilai lain dan kemantapan, dan prioritas nilai yang telah dimilikinya. Yang termasuk dalam organisasi ialah konsep tentang nilai. Karakteristik nilai, yakni keterpaduan dari semua sistem nilai yang telah dimiliki seseorang, yang mempengaruhi pola kepribadian dan tingkah lakunya (Sudjana, 2013: 53-54).

3) Tipe Hasil Belajar Psikomotorik

Gerakan refleksi (keterampilan pada gerakan yang tidak sadar), Keterampilan pada gerakan-gerakan dasar, kemampuan perseptual 
termasuk di dalamnya membedakan visual, membedakan auditif motorik dan lain-lain, kemampuan di bidang fisik, misalnya kekuatan, keharmonisan, ketepatan, gerakan-gerakan skill, mulai dari keterampilan sederhana sampai pada keterampilan yang kompleks, kemampuan yang berkenaan dengan non decursive komunikasi seperti gerakan ekspresif, interpretatif (Sudjana, 2013: 54).

b. Faktor-faktor yang Mempengaruhi Hasil Belajar Siswa

Menurut Sunarto faktor yang mempengaruhi hasil belajar siswa antara lain: Faktor intern adalah faktor-faktor yang berasal dari dalam diri seseorang yang dapat mempengaruhi prestasi belajarnya. Diantara faktor-faktor intern yang dapat mempengaruhi prestasi belajar sessorang antara lain: Kecerdasan/intelegensi, besar pengaruhnya terhadap kemajuan belajar. Dalam situasi yang sama, siswa mempunyai tingkat kecerdasan yang tunggi akan lebih berhasil dari pada yang mempunyai tungkat intelligence yang rendah.

Bakat, kemampuan potensial yang dimiliki seseorang untuk mencapai keberhasilan pada masa yang akan datang. Bakat itu mempengaruhi belajar. Minat, adanya minat terhadap objek yang dipelajari akan mendorong orang untuk mempelajari sesuatu dan mencapai hasil belajar yang maksimal. Karena minat merupakan komponen psikis yang berperan mendorong seseorang untuk meraih tujuan yang diinginkan, sehingga ia bersedia melakukan kegiatan berkisar objek yang diminati. Motivasi, motivasi belajar seseorang akan menentukan hasil belajar yang dicapainya. Bahkan dua orang yang samasama menunjukkan perilaku belajar yang sama, namun memiliki motivasi belajar yang berbeda akan mendapat hasil belajar yang relatif berbeda (Khodijah, 2013: 59-60).

Perhatian, untuk dapat menjamin hasil belajar yang baik, maka siswa harus mempunyai perhatian terhadap bahan yang dipealajarinya dan kesiapan, ini perlu diperhatikan dalam proses belajar, karena jika siswa dan padanya sudah ada kesiapan, maka hasil belajarnya akan lebih baik (syah, 2013: 146).

Faktor ekstern adalah faktor-faktor yang dapat mempengaruhi prestasi belajar seseorang yang sifatnya dari luar diri seseorang tersebut. Yang termasuk faktor-faktor ekstern antara lain: Keadaan keluarga cara orang tua mendidik anaknya besar pengaruhnya terhadap bejar anaknya. Suasana rumah yang gaduh dan ramai tidak akan memberi ketetangan kepada anak yang belajar dan latar belakang kebudayaan atau kebiasaan di dalam keluarga mempengaruhi sikap anak dalam belajar (Slameto, 2010: 63).

Keadaan sekolah lingkungan sekolah juga memegang peranan penting bagi perkembangan belajar para siswanya. Lingkungan inimeliputi lingkungan fisik sekolah seperti sarana dan prasarana belajar yang ada, sumber-sumber belajar, media belajar (Syaodih, 2009: 164).

Keadaan masyarakat lingkungan masyarakat di mana siswa atau individu berada juga berpengaruh terhadap semangat dan aktivitas 


\section{BESTARI}

Vol. 18, No. 1, 2021

p-ISSN 1907-1337; e-ISSN 2807-6532

belajarnya. Lingkungan masyarakat di mana warganya memiliki latar belakang pendidikan yang cukup (Syaodih, 2009:165).

\section{Strategi Pembelajaran Inferencing}

Pengertian Strategi pembelajaran adalah suatu kegiatan pembelajaran yang harus dikerjakan guru dan siswa agar tujuan pembelajaran dapat dicapai secara efektif dan efisien dapat disimpulkan bahwa strategi pembelajaran adalahn cara-cara mengajar yang akan dipilih dan digunakan oleh seorang pengajar untuk menyampaikan materi pembelajaran sehingga tujuan pembelajaran dapat dicapai, menurut Kem 1995, (Wina Sanjaya).

Dikutip dari buku Aqib Zainal, Menurut Kozna (1989) strategi pembelajaran adalah setiap kegiatan yang dipilih yaitu yang dapat memberikan fasilitas atau bantuan kepada peserta didik menju tercapainya tujuan pembelajarna tertentu.(Zainal, 2014:68-69).

Menurut Gropper (1990) strategi pembelajaran adalah pemilihan atas berbagai jenis latihan tertentu yang sesuai dengan tujuan pembelajaran yang ingin dicapai. Memerhatikan beberapa pengertian strategi pembelajaran di atas, dapat disimpulkan bahwa strategi pembelajaran merupakan cara-cara yang akan dipilih dan digunakan oleh seorang pengajar untuk menyampaikan materi pembelajaran sehingga akan memudahkan peserta didik menerima dan memahami materi pembelajaran, yang akhirnya tujuan pembelajaran dapat dikuasainya di akhir kegiatan belajar.

\section{Konsep Strategi Inferencing}

Strategi inferencing atau menyimpulkan adalah pemakaian informasi dalam teks untuk menduga makna butir-butir baru, atau melengkapi bagian yang hilang. Strategi ini ditemukan oleh Katherine D. Wiesendanger di Ohio (Guntur, 2009: 193-194).

Strategi inferencing ialah kegiatan akal pikiran manusia bersadarkan pengertian/pengetahuan yang dimiliknya, dapat beranjak mencapai pengertian/pengetahuan yang baru. (Salam,1998: 68). Berdasarkan pendapat tersebut dapat dipahami bahwa keterampilan ini menuntut pembaca untuk mampu menguraikan dan memahami berbagai aspek secara bertahap agar sampai kepada suatu formula baru yaitu sebuah simpulan. Proses pemikiran manusia itu sendiri dapat menempuh dua cara yaitu deduksi dan induksi.

Strategi inferencing atau menyimpulkan ialah proses berpikir yang memperdaya pengetahuan sedemikian rupa untuk menghasilkan sebuah pemikiran atau pengetahuan baru. Menurut Mestika Zed (2003: 3) strategi inferencing bertujuan untuk mencari atau menguji pengetahuan yang bersifat umum yang disebut generalisasi atau pernyataan yang menyatakan hubungan antar konsep-konsep dan berfungsi sebagai pembantu untuk berpikir dan mengerti. 
Menurut Robert H. Ennis (2000) yaitu: strategi inferencing atau menarik kesimpulan ialah penarikan kesimpulan yang benar harus didasarkan pada langkah-langkah dari alasan-alasan ke kesimpulan yang masuk akal atau logis. Kesimpulan dapat melahirkan sesuatu yang baru yang dapat berperan sebagai fokus untuk di pikirkan,sedangkan alasan merupakan dasar bagi suatu proses penarikan kesimpulan. Inferencing meliputi mendeduksi dan mempertimbangkan hasil deduksi, menginduksi dan mempertimbangkan induksi.

Dari beberapa penegrtian diatas dapat disimpulkan bahwa strategi inferencing ialah merupakan sebuah proses berpikir yang memberdayakan pengetahuannya sedemikian rupa untuk menghasilkan sebuah pemikiran atau pengetahuan yang baru.

a. Kelebihan dan Kekurangan Strategi Pembelajaran Inferencing

Kelebihan: Siswa dapat menentukkan keakuratan pernyataan, verifikasi pernyataan dengan menggunakan bacaan, mengeliminasi pernyataan yang berlebihan dan menghilangkan pernyataan yang tidak relevan (Weisendanger dan Bader, 2001: 190).

Kekurangan: Sulit mengatasi perbedaan dalam hal kemampuan siswa, melalui pemahaman membaca langsung, informasi tidak dapat diperoleh dengan cepat, seringkali menyita banyak waktu (Weisendanger dan Bader, 2001: 190).

b. Langkah-langkah Strategi Pembelajaran Inferencing

Guru meminta siswa membaca bacaan yang telah disediakan dan memilih kata kunci dari bacaan yang telah disediakan, guru memberikan potongan kertas kepada siswa. Siswa menulis kalimat lengkap pada setiap potongan kertas dengan mengacu pada kata kunci. siswa melakukan kerja kelompok untuk menyampaikan pernyataan, dan menyeleksi pernyataan yang tidak relevan, setelah melakukan diskusi kelompok Mereka menarik kesimpulan dari fakta yang ditemukan dalam bacaan dan setiap kelompok menyampaikan kesimpulan, sedangkan kelompok lain menanggapi (Weisendanger dan Bader, 2001: 191).

\section{METODE}

Metode penelitian yang digunakan adalah metode Penelitian Tindakan Kelas (PTK) dengan model Kurt Lewin. Adapun urutan kegiatan dari model Kurt Lewin adalah perencanaan (planning), pelaksanaan tindakan (acting), pengamatan (observing) dan refleksi (reflecting). Teknik pengumpulan data yang digunakan dalam penelitian ini adalah teknik tes, observasi, wawancara dan analisis deskriptif. Analisis datanya seleksi data, pengoreksian data dan pembobotan data. 
BESTARI

Vol. 18, No. 1, 2021

p-ISSN 1907-1337; e-ISSN 2807-6532

\section{HASIL PENELITIAN DAN PEMBAHASAN}

Berdasarkan hasil penelitian diatas, dapat disimpulkan bahwa siklus I nilai evaluasi peserta didik kelas III hanya mencapai 83,05 dengan jumlah peserta didik yang tuntas adalah 12 peserta didik. Hal ini dilihat dari beberapa peserta didik yang telah memahami kegiatan kelompok dengan menggunakan strategi Inferencing, sedangkan sisanya sebanyak 5 peserta didik belum mampu mencapai nilai KKM dikarenakan beberapa peserta didik yang kurang memahami. Refleksi Siklus I ada beberapa yang harus diperbaiki dalam pembelajaran siklus I diantaranya: Dalam aspek rencana pelaksanaan pembelajaran yaitu kurang rinci dan sumber pelajaran hanya satu sumber saja dan dalam proses pembelajaraan yaitu kurang berinteraksi dengan peserta didik dan penyampaian materi harus jelas.

Dari data hasil pengamatan observer terhadap pelaksanaan pembelajaran pada tindakan siklus II mendapat nilai 83,87. Pada siklus II guru memperbaiki kekurangan pada siklus I sehingga nilai pelaksanaan pembelajaran pada siklus II mengalami peningkatan. Refleksi Siklus II Ada beberapa yang harus diperbaiki dalam pembelajaran siklus II diantaranya: Dalam aspek rencana pelaksanaan pembelajaran yaitu kurang memperjelas materi yang disampaikan. Dalam proses pembelajaraan yaitu kurang mengkondisikan kelas sehingga materi kurang tersampaikan

Berdasarkan hasil penelitian diata, dapat disimpulkan bahwa nilai evaluasi peserta didik kelas III hanya mencapai 92,88 dengan jumlah peserta didik yang tuntas adalah 17 peserta didik. Hal ini dilihat dari peserta didik yang telah memahami kegiatan kelompok dengan menggunakan strategi Inferencing. Refleksi Siklus III Ada beberapa yang harus diperbaiki dalam pembelajaran siklus III Dalam aspek rencana pelaksanaan pembelajaran tergolong sangat baik kelengkapannya. Dalam proses pembelajaraan yaitu kurang mengkondisikan kelas. Adapun kemampuan peserta didik dalam menyelesaikan soal evaluasi pada mata pelajaran SKI materi bukti-bukti kerasulan Nabi Muhammad Saw dengan menggunakan strategi Inferencing adalah 92,88 dengan jumalah peserta didik yang mencapai ketuntasan adalah 17 peserta didik.

Berdasarkan analisis dan refleksi terhadap pelaksanaan tindakan kelas yang berlangsung selama tiga siklus, ternyata penelitian ini dapat membuktikan :1) Perencanaan pembelajaran yang disusun dengan baik berpengaruh terhadap pelaksanaan pembelajaran atau kemampuan mengajar guru, sehingga dari tiga siklus yang dilaksanakan apabila nilai RPP meningkat maka nilai mengajar guru pun meningkat. Dapat dilihat dari hasil perencanaan pembelajaran pada tiga siklus yaitu siklus pertama mencapai nilai rata-rata 82,61, siklus kedua mencapai nilai rata-rata 86,5, dan siklus ketiga mencapai nilai rata-rata 93,14. 2) Kemampuan guru dalam melaksanakan pembelajaran juga berpengaruh terhadap hasil belajar peserta didik, ketiga siklus yang dilaksanakan dalam penelitian 
tidakan kelas pada tiap siklusnya mengalami peningkatan yaitu siklus pertama mendapatkan nilai rata-rata 79.02, siklus kedua mencapai nilai rata-rata 83,87, dan siklus ketiga mencapai rata-rata 93,33. 3) Pelaksanaan pembelajaran SKI dengan materi bukti-bukti kerasulan Nabi Muhammad Saw dengan menggunakan strategi Inferencing ternyata berhasil meningkatkan hasil belajar peserta didik di kelas III MIS Rijalul Hikam Jatinagara Kecamatan Jatinagara Kabupaten Ciamis. Hal tersebut dapat terlihat dari hasil observasi terhadap hasil belajar peserta didik. Adapun nilai pada siklus pertama mencapai nilai rata-rata 83,05 , siklus kedua mencapai nilai rata-rata 88,23 , dan siklus ketiga mencapai nilai rata-rata 92,88.

Keberhasilan peningkatan hasil belajar siswa melalui strategi Inferencing dalam pembelajaran Sejarah Kebudayaan Islam pada penelitian ini mulai dari siklus I, siklus II dan siklus III mengalami peningkatan. Dari hasil penelitian ini terbukti bahwa pembelajaran Sejarah Kebudayaan Islam (SKI) berdasarkan perkembangan antar siklus dapat dinyatakan bahwa strategi pembelajaran Inferencing berhasil meningkatkan hasil belajar siswa MI Rijalul Hikam Jatinagara Kecamatan Jatinagara Kabupaten Ciamis.

\section{KESIMPULAN}

Rencana Pelaksanaan Pembelajaran (RPP) pada Penelitian Tindakan Kelas guru sudah semakin baik sehingga rata-rata skor dari siklus pertama sampai tiga mengalami peningkatan. Siklus pertama memperoleh rata-rata skor 82,61 , siklus kedua memperoleh rata-rata skor 86,5. Dan siklus ketiga memperoleh rata-rata 93,14. Dari setiap siklus dalam membuat RPP, mengalami peningkatan hal ini tidak lepas dari masukan observer untuk memperbaiki setiap kesalahan dan menambahkan setiap kekurangan dalam RPP, sehingga RPP yang dipersiapkan semakin lebih baik lagi. Pelaksanaan proses pembelajaran terhadap kemampuan mengajar guru sudah semakin baik pada tiga siklus mengalami peningkatan dari siklus pertama memperoleh rata-rata skor 79,02, siklus kedua memperoleh rata-rata skor 83,87 dan siklus ketiga memperoleh rata-rata skor 93,33. Hasil belajar siswa mengalami peningkatan dari beberapa aspek yaitu nilai pengetahuan peserta didik siklus pertama memperoleh nilai 83,05, siklus kedua memperoleh nilai 88,33 dan siklus ketiga memperoleh nilai 92,88. Dengan demikian strategi Inferencing berhasil meningkatkan hasil belajar siswa. 


\section{DAFTAR PUSTAKA}

Asep, Jihad. (2013). Evaluasi Pembelajaran. Yogyakarta: Multi Presindo Guntur, Henry. (2009). Strategi Pengajaran Pembelajaran Bahasa. Bandung: Angkasa

Hamalik, Oemar. (2001). Proses Belajar Mengajar. Jakarta: Bumi Aksara

Khodijah, Nyayu. (2014). Psikologi Pendidikan. Jakarta: PT Rajagrafindo Persada

Muhibbin, Syah. (2000). Psikologi Pendidikan. Bandung: Remaja Rosdakarya

Muslich, Mansur. (2009). KTSP Pembelajaran Berbasis Kompetensi Dan Kontekstual. Jakarta: Bumi Aksara.

Ramayulis. (2008). Ilmu Pendidikan Islam. Jakarta: Kalam Mulia

Mahanani, Siwi. (2013). Keefektifan Penggunaan Strategi Inferencing Dalam Pembelajaran Membaca Pemahaman. Yogyakarta

Slameto, Arifin. (2010). Belajar Dan Faktor-faktor yang mempengaruhinya. Jakarta: PT Rineka Cipta.

Sudjana, Nana. (2013). Dasar-dasar Proses Belajar Mengajar. Bandung: Sinar Baru

Wiseendanger, Katherine. (2001). Strategies For Literacy Education. Alferd University. 
